\title{
THE ROLE PLAYED BY HUMAN DIGNITY IN RELIGIOUS- DISCRIMINATION DISPUTES
}

\author{
Radley Henrico \\ BProc LLB LLM \\ Senior Lecturer, Public and Procedural Law \\ University of Johannesburg \\ Advocate of the High Court of South Africa
}

\section{SUMMARY}

Intrinsic to being human is the fact that we all have the right to human dignity - to self-worth, autonomy and the ability of self-determination. When dealing with religious discrimination, by default notions of inequality and more specifically unfair or disadvantaged discrimination come to the fore. In the assessment of such discrimination disputes it is interesting to note the extent to which the courts have viewed equality through the prism of human dignity. In this sense human dignity can be said to take central stage so-to-speak in the arena of discrimination dispute resolution. The rationale for this must be premised on the fact that human dignity is far more than just a constitutional right; it is an imperative that jurisprudentially attaches itself to the fact that unfair discrimination on the ground of religion impacts adversely on what and who we are as individuals.

\section{$1 \quad$ INTRODUCTION}

Our 1996 Constitution provides that everyone has inherent dignity and the right to have their dignity respected and protected. ${ }^{1}$ Dignity is one of the values upon which the Republic of South Africa is founded. ${ }^{2}$ In point of fact, we find that human dignity is used together with equality and freedom in a number of other constitutional provisions. ${ }^{3}$ With reference to the constitutional order, dignity has been earmarked as one of the essential imperatives as is apparent from the statement by former Chief Justice Chaskalson who said:

"The affirmation of [inherent] human dignity as a foundational value of the constitutional order places our legal order firmly in line with the development of constitutionalism in the aftermath of the second-world war."

\section{S 10.}

In terms of $\mathrm{s} 1$ together with equality, human rights and freedom.

S 7(1), 36 and 39.

Chaskalson "Human Dignity as a Foundational Value of our Constitutional Order" 200016 SAJHR 193 196; and Currie and De Waal The Bill of Rights Handbook 5ed (2010) 272. For further reading on dignity, see Rosen Dignity: Its History and Meaning (2012); Hepple 


\begin{abstract}
Albie Sachs has also pointed out that:
"Respect for human dignity is the unifying constitutional principle for a society that is not only particularly diverse, but extremely unequal [...] [An open and democratic society] acknowledges the foundational character of the principle of human dignity, and aspires to accept people for who they are. It presupposes diversity and welcomes and treats everyone with equal concern and respect."
\end{abstract}

When religious-discrimination disputes are examined it becomes apparent that apart from considering the case in terms of the equality provisions of legislation and the Constitution, our courts also include in their analysis the impact that unfair discrimination has had upon the complainant's dignity. The purpose of this paper is to focus on the reason courts consider dignity as they do. This is especially noteworthy, since dignity is generally a standalone right and not always a prerequisite to establishing whether unfair discrimination has occurred. An international comparison will also be undertaken with Germany to investigate the extent the right to dignity is considered when assessing religious-discrimination matters. Germany has been chosen on account of its superabundant influence exerted upon our jurisprudence.

\title{
2 LEGAL FRAMEWORK
}

\section{Constitutional provisions}

Rights to freedom of religion, freedom of conscience, thought, belief and opinion are expressly provided for by the Bill of Rights. ${ }^{7}$ These rights are underscored by the right to equality ${ }^{8}$ and more specifically that neither the State nor a private person ${ }^{9}$ may discriminate unfairly, directly or indirectly, against anyone on various grounds including religion. ${ }^{10}$ Moreover, cultural, religious and linguistic communities may not be denied their right to practise

Equality: The New Legal Framework (2011) 14-16; Dworkin Justice for Hedgehogs (2011) 191-218; and Sulmasy "Human Dignity and Human Worth" in Malpas and Lickiss (eds) Perspectives on Human Dignity: A Conversation (2007) 9 10-16.

5 Sachs The Strange Alchemy of Life and Law (2011) 213-214.

6 See Fredman "Providing Equality: Substantive Equality and the Positive Duty to Provide" 2005 SAJHR 163170 173-175 179; Gas "Introduction to South African Constitutional Law. The Constitution-making Process and Some Important Constitutional Issues" 291297 http://www.google/url\%2.Frevistas.um.pdf (23-01-2014); Fedsure Life Assurance v Greater Metropolitan Council 1999 (1) SA 374 (CC) par 56; De Waal "A Comparative Analysis of the Provisions of German Origin in the Bill of Rights" 1995 SAJHR 1; Du Plessis "Learned Staatsrecht from the Heartland of the Rechstaat" 2005 PER 77 78; and Venter "Why Should the South African Constitutional Court Consider German Sources: Comment on Du Plessis and Rautenbach" 2013 German LJ 1579 1581-1584.

S 15(1).

S 9.

9 It is submitted that "person" refers to a natural as well as juristic person considering the fact that the Bill of Rights operates both horizontally and vertically in terms of $s$ (8)(2) of the Bill of Rights. See also AAA Investments v Micro Finance Regulatory Council 2006 BCLR 1255 (CC).

$10 \mathrm{~S} 9(3)$ 
their religion, enjoy their culture or use their language. ${ }^{11}$ Such rights are superior rights given the fact that the Constitution is the supreme law of the land. ${ }^{12}$ The supremacy of such rights ${ }^{13}$ is further buttressed by their containment in the Bill of Rights - the cornerstone of our democracy which enshrines the rights of all people in our country and affirms democratic values of human dignity, equality and freedom. ${ }^{14}$ Moreover, such special cluster of rights must be respected, protected and fulfilled. ${ }^{15}$ The manner in which such rights are to be interpreted and the purposive meaning to be attached thereto do not fall within the present scope of this paper. ${ }^{16}$ Informing the special cluster of rights is the South African Charter of Religious Rights and Freedoms (the SACRRAF). ${ }^{17}$

\section{Legislative provisions}

There are two mainstream legislative sources dealing with religious discrimination, alternatively regulating unfair discrimination on grounds of religion. First is the Labour Relations Act. ${ }^{18}$ Second is the Employment Equity Act (EEA).$^{19}$ Subsidiary to the aforesaid, but no less important, is the Promotion of Equality and Prevention of Unfair Discrimination Act (PEPUDA). ${ }^{20}$ The interpretation of PEPUDA must give effect to the Constitution and its provision on equality. ${ }^{21}$ So too, must it give effect to any relevant law, such as the LRA or EEA or code of practice. ${ }^{22}$ PEPUDA is geared more to govern unfair-discrimination issues as they arise in sectors other than the workplace, ${ }^{23}$ whereas the LRA and EEA, as the names would suggest, are more streamlined to deal with workplace-related unfairdiscrimination matters.

The purpose of the LRA is set out as follows:

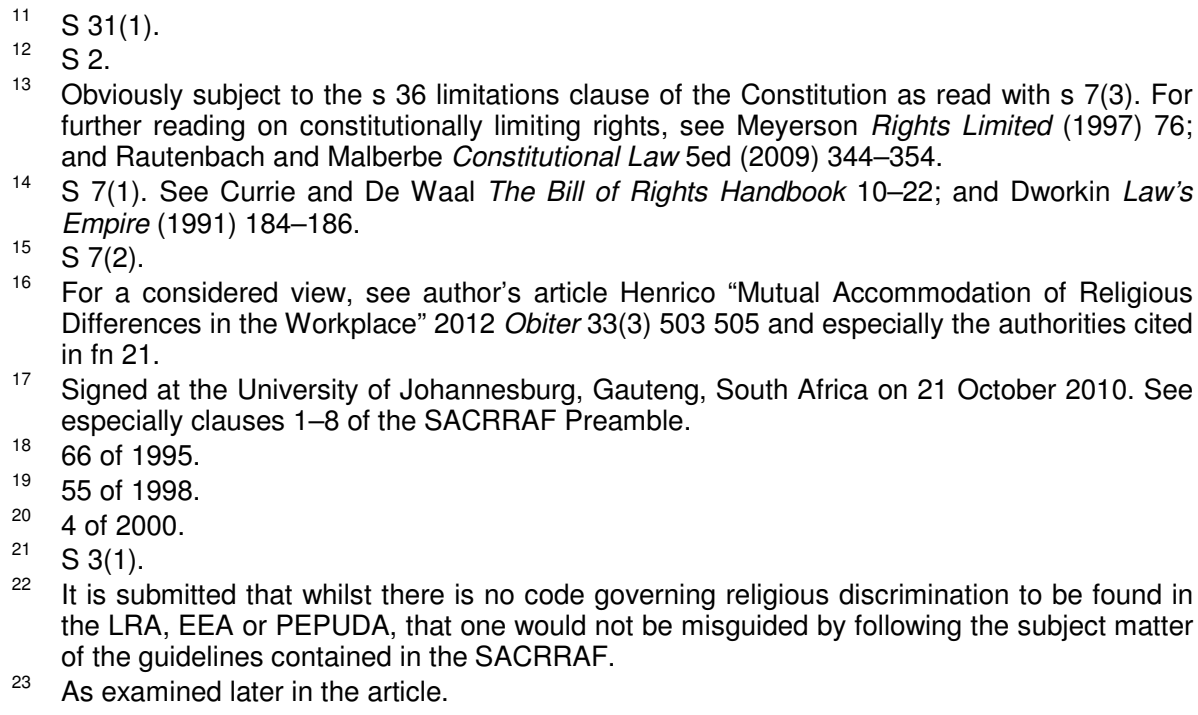

Obviously subject to the $s 36$ limitations clause of the Constitution as read with s 7(3). For further reading on constitutionally limiting rights, see Meyerson Rights Limited (1997) 76; and Rautenbach and Malberbe Constitutional Law 5ed (2009) 344-354.

14 S 7(1). See Currie and De Waal The Bill of Rights Handbook 10-22; and Dworkin Law's Empire (1991) 184-186.

16 For a considered view, see author's article Henrico "Mutual Accommodation of Religious Differences in the Workplace" 2012 Obiter 33(3) 503505 and especially the authorities cited in fn 21.

17 Signed at the University of Johannesburg, Gauteng, South Africa on 21 October 2010. See especially clauses $1-8$ of the SACRRAF Preamble.

1866 of 1995.

1955 of 1998.

204 of 2000 .

22 It is submitted that whilst there is no code governing religious discrimination to be found in the LRA, EEA or PEPUDA, that one would not be misguided by following the subject matter of the guidelines contained in the SACRRAF.

${ }^{23}$ As examined later in the article.

15 S 7(2).

$21 \quad S 3(1)$. 
"[...] to advance economic development, social justice, labour peace and the democratisation of the workplace by fulfilling the primary objects of [the LRA], which are -

(a) to give effect to and regulate the fundamental rights conferred by $523^{24}$ of the Constitution;

(b) to give effect to the obligations incurred by the Republic as a member state of the International Labour Organisation;

(c) to provide a framework within which employees and their trade unions, employers and employers' organisations can -

(i) collectively bargain $[\ldots]^{, 25}$

One ILO obligation that is particularly pertinent is Convention 111 of $1958^{26}$ which, inter alia, defines discrimination to include any distinction on the basis of religion ${ }^{27}$ and also provides for a ground of defence to discrimination if the preference or exclusion or distinction is made on the basis of the inherent requirement of the job. ${ }^{28}$

Specific provision is made in the LRA for an automatically unfair dismissal in the event of an employer discriminating unfairly against an employee ${ }^{29}$ on grounds of religion. ${ }^{30}$ An employee who is so dismissed may be entitled to a maximum sum of 24 months' compensation in the event of a successful adjudication of the matter in the Labour Court. ${ }^{31}$ Whilst the employee would be required to discharge the onus on a balance of probabilities of proving a dismissal, ${ }^{32}$ the onus would rest on the employer, also to be discharged on a balance, of showing that the dismissal on grounds of religion was fair ${ }^{33}$ due to the inherent requirements of the job or that accommodating the employee's religion would work an undue hardship against the employer. ${ }^{34}$

In its Preamble, the EEA states its purpose as being, inter alia, to:

"promote the constitutional right to equality and the exercise of true democracy;

eliminate unfair discrimination in employment;

[...] to redress the effects of discrimination; and

to give effect to the obligations of $_{35}$ the Republic as a member of the International Labour Organisation".

Unfair discrimination which is proscribed in terms of the EEA is dealt with under the provisions of direct and indirect discrimination ${ }^{36}$ and provision is

24 Which deals with labour relations and in particular sub-section (1) provides that everyone has the right to fair labour practices.

S 1 .

26 Convention on Discrimination (Employment and Occupation).

Article 1(1)(a).

Article 1(2).

29 This would obviously include an applicant for employment. See Wyeth $v$ Manqele [2005] ZALAC 1 par 14; 45 and 52.

$30 \quad \mathrm{~S} 187(1)(\mathrm{f})$ read with $\mathrm{S} 1(\mathrm{~b})$ and $3(\mathrm{c})$.

31 S 194(3).

32 In terms of $s$ 192(1). Dismissal is defined in s 186(1)(a)-(f) of the LRA

3 In terms of $s$ 192(2).

34 Dhlamini v Green Four Security 200611 BLLR 1074 (LC).

35 In s 3(d) express reference is made to the ILO Convention 111. 
made for the fact that it is not unfair discrimination to distinguish, exclude or prefer a person where the ground for doing so is affirmative-action related ${ }^{37}$ or based on the inherent requirements of the job. ${ }^{38}$ It is submitted that whether applying the LRA or EEA, the additional defence ground of reasonable accommodation is germane. It is incumbent on the employer to prove the fairness of discrimination where same is alleged and found to have taken place. ${ }^{39}$ Unlike the LRA, where only a ceiling is set on compensation and the form of remedy, namely compensation or reinstatement, in terms of the EEA the Labour Court may, in addition to awarding compensation, award, inter alia, damages to be paid by the employer to the employee. ${ }^{40}$

The State President assented to the amendment of the EEA ${ }^{41}$ by the Employment Equity Amendment Act (EEAA), ${ }^{42}$ a date for coming into operation thereof must still be announced. Some of the most significant proposed changes envisaged are:

"(1) the insertion in $s_{43} 6$ of discrimination, directly or indirectly, on any other arbitrary ground;

(2) an employee may refer an unresolved dispute directly to arbitration without procuring the consent of the opposing party;

(3) if unfair discrimination on a listed ground in $\mathrm{s} 6$ is alleged, the employer defending such allegation must prove, on a balance, that such discrimination did not take place or is rational and not unfair or is otherwise justifiable;

(4) if unfair discrimination is alleged on an arbitrary ground, the complainant employee must prove on a balance that the conduct complained of is not rational ${ }^{6}$ the conduct amounts to discrimination and the discrimination is unfair."

It is submitted that far-reaching implications exist in terms of issues of burden of proof. Evidently, the legislature has widened the gamut of what is required to be proved, especially in the area of discrimination on an arbitrary ground. It may well be argued that such widening of the girth of the onus of proof does not affect religious-discrimination disputes. However, the current wording of the EEA which provides the employer with basically two defences, namely affirmative action or inherent job requirement is now increased to proving that the discrimination was rational and not unfair or is otherwise justifiable. Surprisingly, no support for the proposed altered wording of the Act can be found in ILO Convention 111. It will be of interest

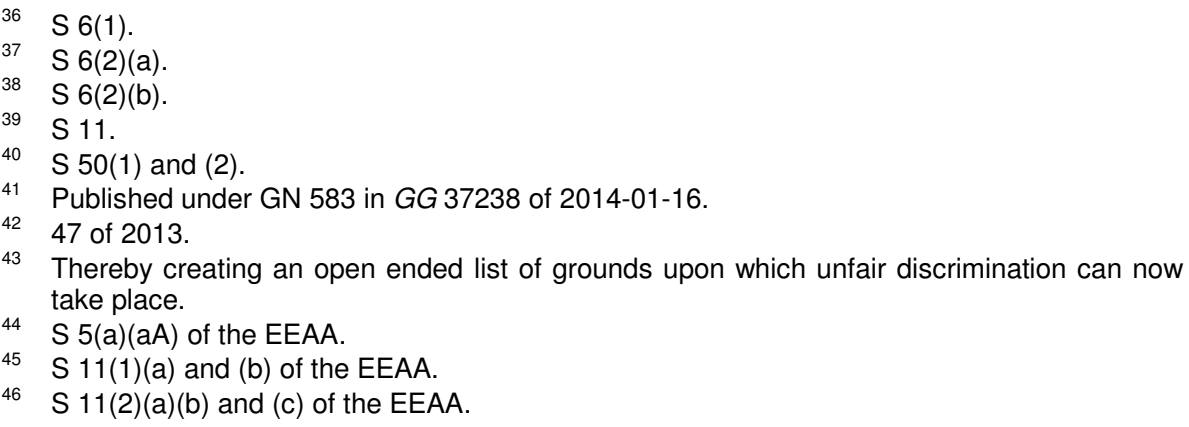


to see how our courts grapple with the new wording and onus introduced by the EEAA. ${ }^{47}$

PEPUDA has as its objective the:

"promotion of equality; the prevention of unfair discrimination and protection of human dignity as contemplated in sections 9 and 10 of the Constitution; to provide for procedures for the determination of circumstances under which discrimination is unfair; and to provide remedies for victims of unfair discrimination."

It is clear that the aforesaid provisions are sufficiently broad to have application to an applicant for employment as well as employees and in particular non-employees. Compared with the LRA, EEC or even the EEAA, PEPUDA is the only legislation where we see an express nexus between unfair discrimination and human dignity by virtue of use of the article "and". Once discrimination on a prohibited ground of PEPUDA has been established $^{49}$ there is a rebuttable presumption of the discrimination being unfair unless the respondent can prove $e^{50}$ that the discrimination is fair. ${ }^{5}$ What is fair would depend on a list of facts and circumstances included, but not limited, to matters such as:

"(1) whether the discrimination impairs human dignity;

(2) the impact or likely impact of the discrimination upon the complainant;

(3) the position of the complainant in society;

(4) the nature and extent of the discrimination;

(5) whether there has been systemic discrimination;

(6) whether the discrimination has a legitimate purpose;

(7) whether and to what extent the discrimination achieves its purpose;

(8) whether there are less restrictive means to achieving the purpose ${ }^{52}$

(9) whether and to what extent the respondent has taken steps that are reasonable in the circumstances to address the disadvantage or accommodate the diversity."

Clearly, the legislature can be lauded for making a conscious effort to set out guidelines that a court should take into account when considering whether a respondent has discharged the onus of showing the discrimination to be fair.

\section{Common-law considerations}

In MEC for Education, Kwazulu, Natal $v$ Pillay ${ }^{54}$ the court was concerned with whether allowing a female teenager to wear a nose stud was to be

\footnotetext{
47 For an informative criticism of the amendments see Submission on the Employment Equity Amendment Bill of 2012 (as introduced by the Minister of Labour (National Assembly)) http://www.pmg.org.za/files/130807dutoit.pdf accessed 2014-01-22.

48 S 2.

49 On a balance of probabilities.

50 Ibid.

S 13(2)(a).

This constitutes, it is submitted, a proportionality test.

3 14(2).
} 
permitted, given that same was contrary the dress code of the school. Of particular concern for the court was whether ordering the removal thereof constituted a discriminatory practice in contravention of the provisions of PEPUDA. Sunali, the schoolgirl in question was required to show that the requirement to remove the nose stud was discrimination on the ground of religion, ${ }^{55}$ whilst the respondent bore the onus of proving that the conduct was not based on one of the prohibited grounds ${ }^{56}$ or that the discrimination was fair. ${ }^{57}$ Chief Justice Langa $\mathrm{J}$, in penning the majority decision, ${ }^{58}$ made the following observation:

"[...] cultural convictions or practices may be as strongly held and as important to those who hold them as religious beliefs are to those more inclined to find meaning in a higher power than in a community of people. The notion that 'we are not islands unto ourselves' is central to the understanding of the individual in African thought. It is often expressed in the phrase umuntu ngumuntu ngabantu which emphasises 'communality and the inter-dependence of the members of the community' and that every individual is an extension of others."

and that:

"This thinking emphasises the importance of community to individual identity and hence to human dignity. Dignity and identity are inseparably linked as one's sense of self-worth is defined by one's identity."

Finally, Langa CJ refers to the fact that:

"[...] religious and cultural practices are protected because they are central to human identity and hence to human dignity which is in turn central to equality."

"Central" to the aforesaid reasoning appears to be the be a macro-notion of a community of human beings from whence we derive our sense of being as individuals which inform the micro-notion of our sense of self-worth, namely dignity - we are what we are simply on account of the fact of where we originate from and given our humane matrix. A reading of the judgment makes it clear that dignity forms an inexorable part of the concept of giving effect to substantive equality. Put differently, it is not equal treatment that one is seeking, but treatment according to one's diversities and differences

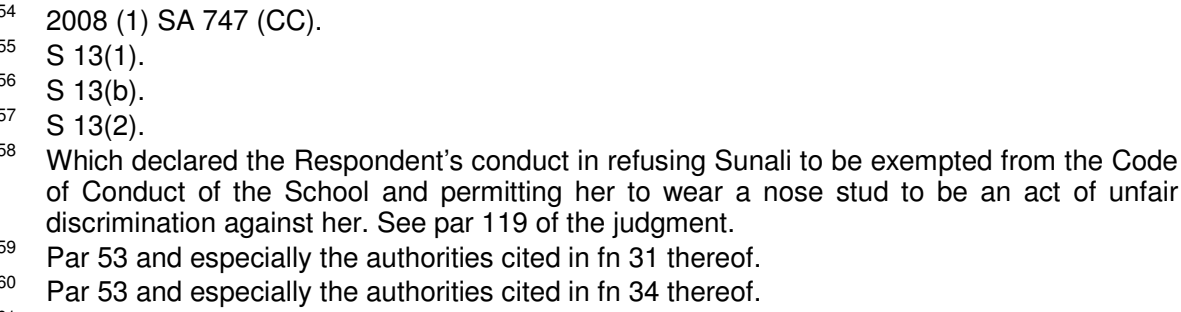


which one seeks to have respected in a heterogeneous and complex society. ${ }^{62}$

Human dignity did not at first blush form part of any of the essential requirements of what Sunali was required to prove. However, in terms of the criteria set out in section 14(2) of PEPUDA, the court considered whether the discrimination impaired or was likely to impair the human dignity of Sunali. ${ }^{63}$ One cannot but sense that the court in Pillay in effect imported dignity as more than just a formal criteria to be considered especially in light of the observation by Langa $\mathrm{CJ}$ that human dignity is central to equality. Given the central role accorded dignity to the role of equality one is almost tempted to view equality through the prism of human dignity. Corroboration for this central role played by human dignity is to be found in the observation that equality relies for its life-blood on the right to human dignity. ${ }^{64}$ Moreover human dignity is a social value attached to human beings acknowledging their autonomous self-worth, ${ }^{65}$ thereby forming an inseparable ingredient of the right to equality in the substantive sense. ${ }^{6}$

In Prince $v$ President, Law Society ${ }^{67}$ the applicant sought to be admitted as an attorney. His application was opposed by the Law Society on the basis that he was not a fit and proper person, having had two previous convictions relating to dagga, and that Prince had expressly stated that he intended to continue smoking the substance since it formed part of his Rastafari religious-belief system. Although the court found that Rastafari was a religion entitled to be protected, it was not an absolute right inasmuch as members, like Prince, had attacked the constitutionality of the Drugs and Drug Trafficking Act. ${ }^{68}$ In recognizing the right to freedom of religion as "probably being one of the most important of all the human rights [since] [r]eligious

62 In her separate judgment, O'Regan J, par 177 comments that an exemption from the code of conduct is something that would have contributed to the "enhancement of human dignity and autonomy".

63 S 14(3)(a).

64 Provided for in s 10 of the Constitution. See Fredman "Facing the Future: Substantive Equality under the Spotlight" in Dupper and Garbers (eds) Equality in the Workplace: Reflections from South Africa and Beyond (2009) Chapter 219.

65 See Woolman "The Widening Gyre of Dignity" in Woolman and Bishop (eds) Constitutional Conversations (2008) Chapter 12193 212-215. See also Bato Star Fishing $v$ Minister of Environmental Affairs 2004 (4) SA 490 (CC) par 73-75; and Albertyn and Goldblatt "Towards a Substantive Right to Equality" in Woolman and Bishop (eds) Constitutional Conversations (2008) Chapter 14231234.

66 See Garbers "Proof and Evidence of Employment Discrimination under the Employment Equity Act 55 of 1998" 2000 SA Merc LJ 136; Dupper "The Current Legislative Framework" in Dupper (ed) Essential Employment Discrimination Law (2004); McCrudden "Human Dignity and Judicial Interpretation of Human Rights" 2008 European Journal of International Law 655685 and 724; and Fagan "Dignity and Unfair Discrimination: A Value Displaced and a Right Misunderstood" 1998 SAJHR 220. Cf Albertyn and Goldblatt "Facing the Challenge of Transformation: Difficulties in the Development of an Indigenous Jurisprudence of Equality" 1998 SAJHR 248 254; and De Waal "Equality and the Constitutional Court" 2002 SA Merc LJ 141150. 2002 (2) SA 794 (CC).

140 of 1992. 
issues are matters of the heart and faith", ${ }^{69}$ the court went on to consider the issue of religion in the context of human dignity in the following observation:

"The right to freedom of religion is especially important for our constitutional democracy which is based on human dignity, equality and freedom [...] The protection of diversity is the hallmark of a free and open society. It is the recognition of the inherent dignity of all human beings. Freedom is an indispensable ingredient of human dignity."

What distinguishes the Prince case from the Pillay case is the fact that the discrimination in the former was said to exist in national legislation, namely national laws relating to the control of narcotic medication that conflicted with the alleged religious convictions of Mr Prince, whilst in the later Sinali was not afforded an exemption from the Code of Conduct based on her religious beliefs. Common to both matters, however, is the view that human dignity is the bedrock of freedom of religion and moreover a means by which in the greater sense of the meaning freedom will not be realized. Put differently, a denial of human dignity would be an affront and effective slight to freedom and equality.

In Strydom v NG Gemeeente Moreleta Park ${ }^{71}$ the Equality court with reference to PEPUDA and the Constitution had to decide a discrimination case on the basis of an application brought by Strydom against the Church who terminated his contract as an independent contractor in the "kunsteakademie" of the church on account of his homosexual orientation. The church argued that an inherent requirement of someone in the applicant's position was that he could not live in a homosexual relationship since same was out of kilter with the doctrine of the church, ${ }^{72}$ requiring its leadership to teach its doctrines. This in fact proved to be the Achilles heel of the Church's defence since the applicant was not in a leadership position and only taught music to the children. In casu the court attached much weight to the impairment of the applicant's dignity by virtue of the termination of his contract $^{73}$ which impacted adversely upon the applicant in that it resulted in his suffering from depression, being unemployed, being the subject matter of publicity and having to sell his piano. ${ }^{74}$ In point of fact the applicant was awarded an amount of R75 000,00 for the impairment of his dignity. ${ }^{75}$ This impairment arose out of the principal action of being discriminated against on the ground of sexual orientation due to the church's alleged insistence on abiding its religious convictions.

The case highlights the important consequence of being subject to treatment that unfairly discriminates against one and ultimately does not make allowance for one's diversity or differences to be accommodated in a manner that can give effect to substantive equality. As previously stated, human dignity is at the centre of equality and therefore, when unequal

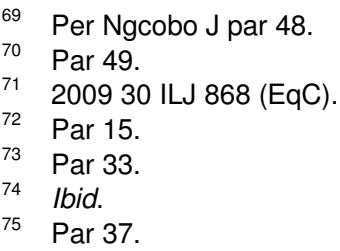


conduct has been meted out in a manner that is disparaging or not in accordance with the spirit and purport of the values of our Bill of Rights, such conduct strikes at the very heart of the human being, adversely impacting upon her dignity.

In the Department of Correctional Services $v$ POPCRU, ${ }^{76} 21$ prison warders were dismissed for refusing to cut their dreadlocks. The dismissed employees insisted that their hairstyles were consistent with their Rastafarian belief and religion and cutting same would infringe their rights, therefore rendering their dismissals automatically unfair on grounds of religious discrimination in terms of the LRA and discrimination in terms of the EEA. Although the cause of action was not based on PEPUDA it is interesting to note that the court used the test that would be used under PEPUDA in deciding whether there had been a contravention of the LRA. ${ }^{77}$

And to this end the court was able to draw on considerations of whether the discrimination had impaired the dignity of the complainants. ${ }^{78}$

In the absence of a duty on the court to draw upon a test as set out in PEPUDA, namely the impairment of dignity, it is noteworthy that the court may very well have decided, it is submitted, the issues before it on the tests as provided for in the LRA and EEA. We can see therefore that impairment of human dignity is crucial to the overall issue of equality and that considerations thereof are not simply germane to academic arguments or philosophies, but to facilitating a more balanced approach in assessing discrimination disputes.

In Christian Education South Africa $v$ Minister of Education ${ }^{79}$ the case involved the application of corporal punishment since it violated the rights of parents at independent schools who consented to the use thereof in accordance with their religious beliefs. The court held that, whilst the parents were not being precluded from bringing the children up according to the dictates of the religious doctrines, they were not allowed to authorize the use of corporal punishment to be inflicted on their children since same was not constitutionally sound and permissible. Sachs $\mathrm{J}$ held the following:

"There can be no doubt that the right to freedom of religion, belief and opinion in the open and democratic society contemplated by the Constitution is important. The right to believe or not to believe, and to act or not to act according to his or her other beliefs or non-beliefs, is one of the key ingredients of any person's dignity. Yet freedom of religion goes beyond protecting the inviolability of the individual conscience. For many believers, their relationship with God or creation is central to all their activities. It concerns their capacity to relate in an intensely meaningfully fashion to their sense of themselves, their community and their universe. For millions in all walks of life, religion provides support and nurture and a framework for individual and social stability and growth. Religious belief has the capacity to

\footnotetext{
2011 ZALAC.

$S$ 187(1)(f).

78 Par 37 and 43. This is in addition to the other tests the court employed, such as the need for reasonable accommodation and the inherent requirement of the job - see par 44-48.

79 [2000] ZACC 11.
} 
awake concepts of self-worth and human dignity which form the cornerstone of human rights.'

The court had regard to the Declaration on the Elimination of All Forms of Intolerance and of Discrimination Based on Religion or Belief which declares that: "Practices of a religion or belief in which a child is brought up must not be injurious to his physical or mental health or his full development [...]., ${ }^{11}$ Whilst the court rejected that the issue should be decided on the basis of equality, ${ }^{82}$ it being argued in the main that equality is aimed not in treating everyone alike, but in "treating everyone with respect and concern" ${ }^{3}$ it accepted the argument that the "state has an interest in protecting pupils from degradation and indignity". ${ }^{84}$ In particular, Sachs J noted that: "[...] the core value of human dignity in our Bill of Rights did not countenance the use of physical force to achieve scholarly correction". ${ }^{85}$

In coming to the assistance of children that had until then been subject to corporal punishment in the name of religion, the court rejected a substantive equality approach and opted rather for an approach based upon dignity.

Dhlamini $v$ Green Four Security ${ }^{86}$ concerned the dismissal of security guards for refusing to shave their beards on the basis that a beard was, according to them, part of their religious belief system. They challenged their dismissal unsuccessfully on the basis of religious discrimination. In analysing the case, the court was of the view that the inherent requirements of the job required security guards to conform to a certain neat appearance that was inconsistent with their beards and, moreover to accommodate the guard's with their beards would have worked an undue hardship on the respondent employer. ${ }^{87}$ The applicants had failed to show that growing beards was a central tenet of their religion, as the warders were able to show in POPCRU. Had the security guards been able to show otherwise, it is submitted that considerations of dignity would have been relevant to deciding the case since it is a core element of equality as well as a vital aspect of freedom of association as has already been pointed out.

\section{3}

\section{GERMANY}

\section{Constitutional and legislative framework}

The 1949 Basic Law for the Federal Republic of Germany, ${ }^{88}$ provides that human dignity shall be inviolable and that to respect and protect it, shall be

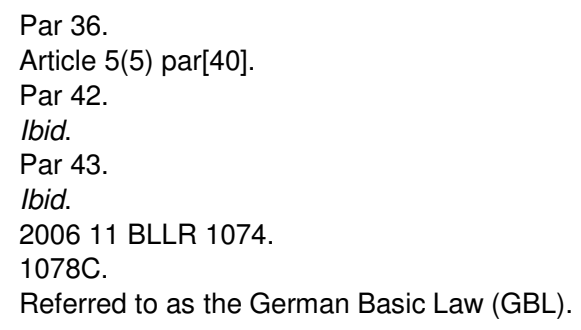


the duty of all State authority. ${ }^{89}$ It goes on to provide that all persons shall be equal before the law ${ }^{90}$ and that no person shall be treated differently on the basis of, inter alia, gender, race, language, faith or religion. ${ }^{91}$ Human dignity is unashamedly set forth as the first principle value of the GBL. However, it has been pointed out that the concept of human dignity as it appears in the GBL can be attributed to its foundation in the 1919 Weimer Constitution. ${ }^{92}$ The alignment of the date with the end of World War One is no meagre coincidence. In terms of obligations imposed on the works council, there is the Works Constitution Act of 1972 which ensures that the works council together with the employer shall ensure the treatment of employees in terms of law and equity and that they are not subjected to unfair discriminatory practices. Other anti-discriminatory legislation is the European Council directive of 1976 which emphasizes the principle of equal treatment for men and women employees or workers. In addition, there is the General Act on Equal Treatment $^{93}$ which is responsible for transcribing the $1976 \mathrm{EC}$ directive and other directives into a single body of written law regulating the prohibition against discriminatory conduct in the workplace. ${ }^{94}$

Whilst the imperative of equality plays a prominent role in monitoring unfair discrimination it is clear that the reference to law is sufficiently broad to include the most basic right, namely human dignity as set out in the GBL. On account of the historical blight on human rights under the apartheid and Nazi regimes, the express provision in our Constitution as well as the GBL of human rights is of imperative significance. ${ }^{95}$ Our Constitutional right to human dignity has been informed by Article 1(1) of the GBL, however, the GBL entrenches, so-to-speak, the right to human dignity even further by making it inviolable and immune from constitutional amendment, ${ }^{96}$ and as a result has been rendered an absolute right. Our human-right entitlement in terms of section 10 is subject to section 36 of the Constitution making it a right that is relative and subject to being balanced against potentially competing rights.

It is said that the German Federal Constitutional Court (BVerfG) has purposefully followed the Kantian concept that "a person may never be treated as a mere object but always as an end in him/herself". ${ }^{97}$ Such a notion would be consonant with upholding and protecting individuals and ensuring they are not unfairly discriminated against. To respect an individual on account of her diversity and to embrace such diversity, whether on the

89 Article 1(1). Where "dignity" is referred to as "Menschenwürde" which mirrors the Afrikaans word "menswaardigheid". See Ackermann Human Dignity: Lodestar for Equality on South Africa (2013) 4.

90 Article 3(1).

1 Article 3(3).

2 Ackermann Human Dignity: Lodestar for Equality on South Africa 115.

93 Passed 14 August 2006.

94 See Weiss "Unfair Discrimination Law - Developments at European Level (with specific reference to the new German Act on Equal Treatment)" in Dupper and Garbers (eds) Equality in the Workplace Reflections from South Africa and Beyond (2009) 63 72-73.

95 Ackermann Human Dignity: Lodestar for Equality on South Africa 116.

96 In terms of Article 79(3) of the GBL.

97 Ackermann Human Dignity: Lodestar for Equality on South Africa 119 
basis of race, gender or religion, must also by necessary implication give effect to the right to human dignity. Ackermann refers to the scholar Jürgen Salzwedel who, when dealing with the GBL Article 3(3), states that:

"Discrimination means to disadvantage in such a way as to harm the personality [...] art 3(3) consequently stands in a much closer relationship to art 1(1) - Human worth - and art 2(1) - 'personality' - than art 3(1) does. [Moreover] in so far as differentiation impinges on the most intimate core of the personality, human worth itself, even the legislature, seeking to amend the Basic Law is prohibited by Art 79(3) from doing so.

This reasoning of the link between human dignity and equality in German jurisprudence echoes what our own courts have said about human dignity being central to the issue of equality and as Ackermann has noted:

"It is difficult to see how any discrimination on an art 3(3) ground could not infringe human dignity [...] I have, despite my own researches and extensive enquiries, been unable to find a case in which discrimination on an art 3(3) ground has been held justified, despite infringing human dignity."

\section{THE DIGNITY FOOTHOLD}

\section{Applying dignity when assessing discrimination disputes}

Discrimination disputes can only be determined and reparation or harmony achieved when they are effectively resolved. Various tests have been invoked by our courts as provided for in ILO instruments, statutory provisions and common-law developments. Optimally the resolution of a discrimination dispute relies on the most effective test to be invoked since this would be germane to economy of time, complexity and practical cost considerations. In Harksen $v$ Lane, ${ }^{100}$ Goldstone J, writing for the majority, took into account the significant role that dignity has to play in discrimination cases when referring to State President of the RSA v Hugo ${ }^{101}$ in which the following was stated:

"[...] At the heart of the prohibition on unfair discrimination lies a recognition that the purpose of our new constitutional and democratic order is the establishment of a society in which all human beings will be accorded equal dignity and respect regardless of their membership of particular groups.

In particular, Goldstone J, refers to the fact that "The prohibition of unfair discrimination in the Constitution provides a bulwark against invasions which impair human dignity or which affect people adversely in a comparably serious manner". ${ }^{103}$ With reference to Hugo, Goldstone $\mathrm{J}$ reiterates that dignity essentially involves an examination of looking at the "experience" of

98 Ackermann Human Dignity: Lodestar for Equality on South Africa 230.

99 Ackermann Human Dignity: Lodestar for Equality on South Africa 234.

100 [1997] ZACC 12.

1011997 (3) SA 1012 (CC).

102 Par 42.

103 Par 50. 
the victim of the discrimination whilst in the greater context concern is aimed at "[...] the impact of the discrimination on the complainant that is the determining factor regarding the unfairness of the discrimination". ${ }^{104}$ One of the factors to be taken into account in deciding whether the discrimination has impacted unfairly on the complainant is to consider, inter alia, whether the discrimination has led to the impairment of the fundamental human dignity of the complainant or "constitutes an impairment of a comparably serious nature". ${ }^{105}$

Viewing dignity and how the discrimination has impaired same should not be understood to be dispositive of the enquiry into the judicial determination of discrimination disputes; that would be a too simplistic approach. Having been listed as a factor to be taken into account accords it significant weight to be considered by our courts. Moreover, it would be far-fetched to submit that human dignity trumps equality rights in the assessment especially if we accept, as we should, that human dignity forms a crucial role of equality. To say it trumps equality would be proverbially to throw the baby out of the tub with the water! $!^{106}$

Ackermann aptly captures the important role played by human dignity in referring to Forrester's remark about human dignity, namely that:

"[...] each person is of finite, and hence equal, worth and should be treated as such ... To affirm human equality is both to say something important about what human beings are, and also how relationships and social institutions should be arranged, and how we should behave to one another."

\section{CONCLUDING REMARKS}

Assessment of religious-discrimination disputes in whatever domain always begs the question of the extent to which the complainant has been disadvantaged. Clearly, if there is no disadvantage there can be no question of having been treated in a harmful way. On the other hand, once disadvantage is shown to exist, harm comes into the equation and the respondent is challenged with having to show that it is a disadvantage which is fair in the circumstances on account of the inherent job requirement, alternatively, something that cannot reasonably be accommodated without causing disproportionate harm to the respondent. At the epicenter of such a query is a substantive equality test, namely that people are not treated equally because they find themselves in equal positions. To do so would be to give effect to the Aristotelian notion of formal equality. ${ }^{108}$ Rather what is

\footnotetext{
Ibid.

105 Par 51.

106 See Du Bois "Rights Trumped? Balancing in Constitutional Adjudication" in Du Bois (ed) The Practice of Integrity: Reflections on Ronald Dworkin \& South African Law (2005) 155 173.

107 Ackermann Ackerman Human Dignity: Lodestar for Equality on South Africa 38.

108 For a discussion on the necessity of a substantive equality instead of a formal equality approach, see Hepple Equality: The New Legal Framework (2011) 4 and 23-24; Van Niekerk, Christianson, McGregor, Smit and Van Eck Law@work 2ed (2012) 121-123; Meyerson Jurisprudence (2011) 351-353; and Du Plessis and Fouche A Practical Guide to
} 
required is that a particular person's diversity be tolerated in a meaningful manner with the purpose of giving effect to such person's worth as an individual. Human dignity will then always be at the hub of an enquiry into equality because we are required to be tolerant, act with a notion of mutual accommodation of our diversities and not objectify the individual. In this sense giving effect to the self-worth of the person is of noble virtue and determinative of assisting in resolving religious-discrimination disputes together with the other tests currently being employed by our courts. 